Krzysztof Kil*, Ewa Miklaszewska**

\title{
DETERMINANTY GENEROWANIA KREDYTÓW GOSPODARCZYCH W OKRESIE POKRYZYSOWYM NA PRZYKŁADZIE POLSKIEGO SEKTORA BANKÓW SPÓŁDZIELCZYCH
}

\section{Wprowadzenie}

Podstawowe znaczenie dla długookresowego wzrostu gospodarczego ma efektywne generowanie kredytów przez banki. Badania źródłowe wskazują, że dostępność kredytu ma pozytywny i statystycznie istotny wpływ na PKB, chociaż czasem trudno wyraźnie określić zależności przyczynowo-skutkowe ${ }^{1}$. Wiele raportów publikowanych w okresie pokryzysowym pokazuje, że podstawową rolę w generowaniu wzrostu odgrywają kredyty bankowe skierowane do przedsiębiorców ${ }^{2}$. Toteż spadek dynamiki kredytów bankowych dla przedsiębiorstw niefinansowych, obserwowany w okresie pokryzysowym, jest szczególnie niepokojący. Jest to istotne zwłaszcza dla Polski, gdyż relatywny udział kredytów gospodarczych do PKB jest w Polsce stosunkowo niski. Celem artykułu jest zatem określenie podstawowych determinant rozwoju akcji kredytowej, ze szczególnym uwzględnieniem wkładu banków spółdzielczych.

Dla krajów Unii Monetarnej kredyt bankowy jest głównym źródłem finansowania gospodarstw domowych (80\%), podczas gdy przedsiębiorstwa mają bardziej zróżnicowane źródła finansowania - 40\% to instrumenty akcyjne, 19\% to dłużne papiery wartościowe, a kredyt bankowy jest dopiero na trzecim miejscu z 16-procentowym

\footnotetext{
* Uniwersytet Ekonomiczny w Krakowie, Wydział Finansów.

** Uniwersytet Ekonomiczny w Krakowie, Wydział Finansów.

1 L. Cappiello, A. Kadareja, Ch. Kok Sørensen, M. Protopapa, Do bank loans and credit standards have an effect on output? A panel approach for the euro area, "ECB Working Paper" 2010, No. 1150.

2 T. Beck, B. Büyükkarabacak, F. Rioja, N. Valev, Who Gets the Credit? And Does It Matter? Household vs. Firm Lending across Countries, "The World Bank Working Paper" 2008, No. 4661; T. Beck, H. Degryse, R. De Haas, N. Van Horen, When Arm's Length Is Too Far: Relationship Banking over the Business Cycle, "EBRD Working Paper" 2014, No. 169.
} 
udziałem $^{3}$. Kredyt bankowy nie jest więc jedynym źródłem finansowania przedsiębiorstw europejskich, również w Polsce, ale źródłem bardzo ważnym i stabilnym. Dlatego niepokojący jest fakt załamania się dynamiki tego typu kredytu w okresie pokryzysowym. Ponadto przyrost kredytów gospodarczych był w okresie 2012-2014 ujemny (rysunek 1).

Rysunek 1. Kredyty instytucji finansowych dla niefinansowego sektora prywatnego na obszarze Unii Monetarnej w podziale na kredyty dla gospodarstw domowych (HH) i dla przedsiębiorstw (NFC) (w \%, zmiana r/r)

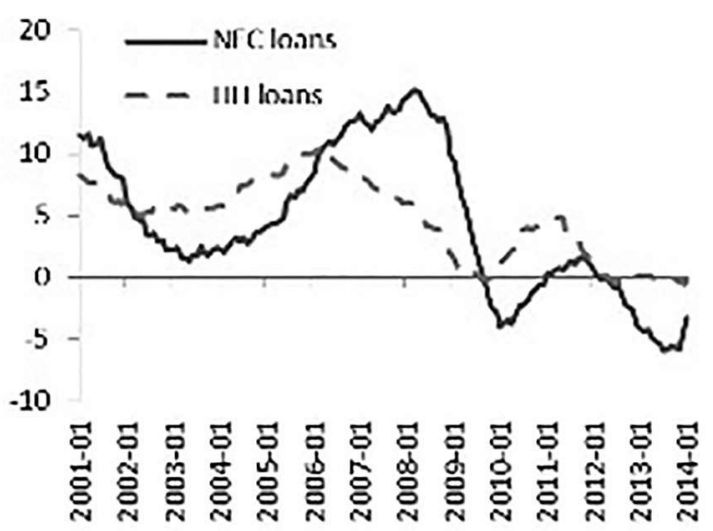

Źródło: Economic Review of the Financial Regulation Agenda, European Commission Staff Working Document, Brussels 2014, s. 205.

Często wskazuje się też, że ograniczenie dostępu do kredytu dla firm jest skutkiem restrykcyjnych regulacji pokryzysowych, które szczególnie silnie dotykają małe banki, w tym banki spółdzielcze ${ }^{4}$.

\section{Rola banków spółdzielczych w kredytowaniu przedsiębiorstw}

Banki spółdzielcze są zdecentralizowanymi instytucjami o dużej elastyczności działania, co może być silnym atutem w kreowaniu strategii i osiąganiu przewagi

3 Economic Review of the Financial Regulation Agenda, European Commission Staff Working Document, Brussels 2014, s. 54.

4 V. Mc Carroll, S. Habberfield, The Outlook for Co-Operative Banking in Europe, Oliver Wyman Report, 2012, www.oliverwyman.com 
konkurencyjnej ${ }^{5}$. Sektor banków spółdzielczych po kryzysie 2008 r. pokazał swoje zalety w wielu krajach. Na przykład w Polsce zwiększył finansowanie sektora przedsiębiorstw w procentowej strukturze kredytów z 20\% do 24\% w okresie 2008-2011, podczas gdy banki komercyjne w tym samym czasie ograniczyły tego typu kredyty z 40\% do 30\%. Tendencja ta dalej się pogłębia - w marcu 2014r. w należnościach od sektora niefinansowego grupa przedsiębiorstw i przedsiębiorców indywidualnych stanowiła $49,5 \%{ }^{6}$. Podobne tendencje wystąpiły w innych krajach o silnym sektorze spółdzielczym, gdzie badania empiryczne pokazały kluczową rolę małych banków, szczególnie dla finansowania sektora MSP i dla lokalnego wzrostu ekonomicznego ${ }^{7}$.

W literaturze toczy się też debata, czy bardziej efektywne jest kredytowanie MSP przez małe lokalne banki, czy duże globalne instytucje. Małe banki, opierając się na bankowości relacyjnej, długotrwałych, bezpośrednich i powtarzalnych relacjach z MSP rozwiązują lepiej problem dostępu do informacji ${ }^{8}$. Z kolei wiele prac wskazuje, że duże banki, oparte na bankowości transakcyjnej (arms-length lending) mają silną przewagę w zakresie technologii kredytowania i w okresie dobrej koniunktury mogą mieć lepszą efektywność niż lokalne banki relacyjne ${ }^{9}$. Badania empiryczne pokazały też, że duże banki uważają segment małych firm za bardzo dochodowy, ale obarczony dużym ryzykiem kredytowym - w krajach wysoko rozwiniętych głównym ryzykiem jest konkurencja, w krajach słabo rozwiniętych niestabilność makroekonomiczna. Główne różnice dotyczyły też stopnia rozwoju - w krajach rozwijających się dostęp do kredytu dla małych firm był z natury trudniejszy, a najważniejszym czynnikiem ryzyka było otoczenie rynkowe ${ }^{10}$.

Dla MSP bankowość relacyjna świadczona przez małe banki ma wiele fundamentalnych zalet - długotrwałe relacje pozwalają na obniżenie kosztów zbierania informacji, a zatem na niższe oprocentowanie i niższe wymogi co do zabezpieczeń w kredytowaniu MSP. Bankowość relacyjna pozwala też na antycykliczność kredytowania, gdyż jest bardziej stabilna i pozwala na utrzymanie finansowania małych firm także w fazie recesji czy kryzysu ${ }^{11}$. Rola podejścia relacyjnego okazała się szczególnie istotna po kryzysie 2008 r. jako ważny czynnik utrzymania dynamiki kredytowania. W badaniach empirycznych wskazano również, że bankowość transakcyjna

\footnotetext{
5 Zob. McKinsey on Cooperatives, McKinsey \& Co., 2012, www.mckinsey.com

6 Informacja o sytuacji banków spółdzielczych i zrzeszających w I kwartale 2014 r., KNF, Warszawa 2014.

7 I. Hasan, K. Jackowicz, O. Kowalewski, Ł. Kozłoski, Bank ownership structure, SME lending and local credit markets, "Bank of Finland Research Discussion Paper" 2014, No. 22.

8 A. Boot, Relationship Banking: What Do We Know?, "Journal of Financial Intermediation" 2000, No. 9.

9 T. Beck, A. Demirgüç-Kunt, M. Soledad, M. Peria, Bank Financing for SMEs: Evidence Across Countries and Bank Ownership Types, "Journal of Financial Services Research" 2011, No. 39.

10 T. Beck, B. Büyükkarabacak, F. Rioja, N. Valey, op.cit.

${ }^{11}$ P. Bolton, X. Freixas, L. Gambacorta, P.E. Mistrulli, Relationship and Transaction Lending in a Crisis, "BIS Working Papers" 2013, No. 417.
} 
jest efektywna w czasie dobrej koniunktury, zaś bankowość relacyjna lepiej sprawdza się w okresie kryzysu czy recesji ${ }^{12}$. W bankowości relacyjnej występuje wyższy koszt pozyskania informacji o kliencie i dlatego często w okresie dobrej koniunktury charakteryzuje się ona wyższym kosztem kredytu, jednak zostaje to wyrównane w okresie pogorszenia koniunktury. Bank, znając swojego klienta, na ogół kontynuuje kredytowanie rentownych firm na przedkryzysowych (korzystnych) warunkach. Wynikają stąd wnioski, że jeśli firma ma dostęp do bankowości relacyjnej, dotykają ją w mniejszym stopniu ograniczenia w dostępie do kredytu w okresie złej koniunktury, ale nie w okresie dobrej koniunktury, gdzie typ kredytowania jest mniej istotny ${ }^{13}$.

Również prowadzone na rynku polskim badania potwierdziły, że bankowość relacyjna była bardzo ważna dla polskich przedsiębiorstw i banków w okresie kryzysu. Szczególnie mniejsze przedsiębiorstwa, z mniejszymi potrzebami kredytowymi oraz mniej rentowne, charakteryzujące się większym ryzykiem kredytowym, były bardziej skłonne do finansowania relacyjnego ${ }^{14}$. Dlatego tak istotne jest stwierdzenie, czy wzrost poziomu kredytowania przedsiębiorstw przez banki lokalne, charakteryzujące się podejściem relacyjnym - w Polsce głównie banki spółdzielcze - jest krótkookresowym pokryzysowym zjawiskiem, czy też nowym, długookresowym trendem oraz jakie czynniki decydują o wzroście udziału kredytów gospodarczych w portfelach kredytowych banków spółdzielczych.

\section{Determinanty akcji kredytowej - metoda badawcza}

W części empirycznej artykułu skoncentrowano się na badaniu, na ile polski sektor banków spółdzielczych powiela trendy globalne, analizowane w literaturze przedmiotu, zgodnie z którymi małe banki, oparte na bankowości relacyjnej, pełnią ważną rolę w generowaniu kredytów gospodarczych w okresie pokryzysowym. Podjęto próbę identyfikacji czynników wpływających na kredytowanie przedsiębiorstw przez banki spółdzielcze w Polsce oraz determinant jakości tych ekspozycji kredytowych.

Do oceny czynników wpływających na wielkość kredytowania przedsiębiorstw przez banki spółdzielcze w Polsce w okresie pokryzysowym oraz jakości ekspozycji kredytowych sformułowano następujące hipotezy badawcze:

12 T. Beck, H. Degryse, R. De Haas, N. Van Horen, op.cit.

${ }_{13}$ P. Bongini, M.L. Di Battista, L. Nieri, Relationship banking: an old solution for the present crisis?, BANCARIA, "Bancaria Editrice" 2009, Vol. 5.

${ }^{14}$ Zob. K. Gajewski, M. Pawłowska, W. Rogowski, Relacje firm z bankami w Polsce w świetle danych ze sprawozdawczości bankowej, „Materiały i Studia” 2012, nr 275, NBP. 
- na podaż kredytów gospodarczych przez banki spółdzielcze istotnie wpływają zarówno czynniki makroekonomiczne jak i mikroekonomiczne, jednak ich znaczenie i siła oddziaływania jest różna,

- wewnętrzne zróżnicowanie banków spółdzielczych wpływa na kształt i rozmiary akcji kredytowej.

Hipotezy te testowano za pomocą badania panelowego ze stałymi efektami (przeprowadzono test Hausmana i test Breuscha-Pagana), do którego pozyskano jednostkowe dane bilansowe banków spółdzielczych działających w ramach zrzeszenia BPS S.A. nieprzerwanie w latach $2010-2013^{15}$. W związku z procesami przejęć na polskim rynku bankowym z zakresu analiz wyłączono Bank Spółdzielczy w Branicach, Bank Spółdzielczy w Wysokiem, Bank Spółdzielczy w Dobrem, Bank Spółdzielczy w Łazach, Jurajski Bank Spółdzielczy w Niegowie, Bank Spółdzielczy w Sarnakach (banki przejęte w latach 2010-2013, wykreślone z KRS) oraz Bank Spółdzielczy w Namysłowie, Bank Spółdzielczy w Mińsku Mazowieckim, Bank Spółdzielczy w Wolbromiu i Bank Spółdzielczy w Kornicy (banki przejmujące). Ostatecznie włączono 355 obiektów.

Banki spółdzielcze podzielone zostały na trzy grupy badawcze, według kryterium wartości aktywów na koniec 2013 r.:

- małe banki o sumie aktywów do $75 \mathrm{mln}$ PLN (134 podmioty),

- średnie banki o sumie bilansowej w przedziale 75-150 $\mathrm{mln}$ PLN (114 podmiotów),

- duże banki o wartości aktywów powyżej $150 \mathrm{mln}$ PLN (107 podmiotów).

Zmienną objaśnianą były:

- Kogółem/A - udział kredytów ogółem dla sektora niefinansowego do sumy aktywów,

- Kprz/Kogółem - udział kredytów dla przedsiębiorstw w kredytach ogółem dla sektora niefinansowego,

- Kgd/Kogółem - udział kredytów dla gospodarstw domowych w kredytach ogółem dla sektora niefinansowego.

W ramach regresorów wyodrębniono dwie grupy zmiennych, opisujących czynniki:

a) makroekonomiczne:

- tempo wzrostu gospodarczego mierzone zmianą PKB per capita w cenach stałych dla województwa, w którym bank prowadzi dominującą lub wyłączną działalność - $\triangle$ PKB,

- wysokość stóp procentowych, mierzona średnioroczną wartością stawki WIBOR O/N - WIBOR O/N.

15 Autorzy serdecznie dziękują bankowi BPS S.A. za udostępnienie danych bilansowych oraz Pani Małgorzacie Marciszewskiej z Departamentu Bankowości Spółdzielczej BPS SA za pomoc w weryfikacji i opracowaniu danych źródłowych. 
b) mikroekonomiczne - charakterystyki banku:

- wielkość banku mierzona przez logarytm wartości aktywów - logAktywa oraz zatrudnienie wyrażone jako średnia liczba etatów w ciągu roku - Zatrudnienie,

- efektywność działania mierzona rentownością kapitałów własnych - ROE,

- kapitalizacja banku mierzona wskaźnikiem kapitały własne/suma aktywów - CAR,

- model biznesowy banku, uwzględniający strategię finansowania banku, reprezentowaną przez stosunek depozytów od sektora niefinansowego do kredytów dla sektora niefinansowego - $\mathrm{D} / \mathrm{K}$,

- bezpieczeństwo działania banku, mierzone indeksem Z-score, zdefiniowanym jako iloraz sumy CAR i ROA w danym roku oraz odchylenia standardowego ROA dla lat 2010-2013 - Z-score,

- jakość ekspozycji kredytowych banku, reprezentowana przez udział należności nieregularnych w należnościach brutto od sektora niefinansowego: ogółem - NPL ogółem, dla gospodarstw domowych - NPL gd oraz dla przedsiębiorstw - NPL prz.

Wartości PKB dla województw pozyskano z Banku Danych Lokalnych GUS ${ }^{16}$, przy czym dane za rok 2013 mają charakter szacunkowy ${ }^{17}$. Szacunku średniorocznej stawki WIBOR O/N dokonano z wykorzystaniem danych archiwalnych kwotowań ${ }^{18}$.

\section{Charakterystyka grup banków spółdzielczych w okresie pokryzysowym}

W okresie pokryzysowym, w latach 2010-2013 obserwowany jest dość intensywny wzrost wartości aktywów banków spółdzielczych. W badanej grupie średnio w ciągu trzech lat wartość bilansowa banków spółdzielczych wzrosła o 39,13\%, tj. o 17,88 p.p. więcej niż średnia dla całego polskiego sektora bankowego ${ }^{19}$. Jest

\footnotetext{
${ }^{16} \mathrm{http} / / /$ stat.gov.pl/bdl/app/dane_podgrup.hier?p_id=513702\&p_token=450366141; sekcja rachunki regionalne, dostęp 12.02.2015.

17 Wstępne szacunki produktu krajowego brutto według województw w 2013 r., GUS, 27 stycznia 2015, s. 1, http://stat.gov.pl/obszary-tematyczne/rachunki-narodowe/rachunki-regionalne/wstepne-szacunkiproduktu-krajowego-brutto-wedlug-wojewodztw-w-2013-r-,4,2.html; http://stat.gov.pl/obszary-tematyczne/rachunki-narodowe/rachunki-regionalne/wstepne-szacunki-produktu-krajowego-brutto-wedlugwojewodztw-w-2013-r-,4,2.html, dostęp 10.03.2015.

${ }^{18} \mathrm{http}: / /$ analizy.bgz.pl/charts/depo-rates, dostęp 10.03.2015.

19 Informacje dotyczące sektora bankowego zostały obliczone na podstawie danych KNF, https://www. knf.gov.pl/opracowania/sektor_bankowy/dane_o_rynku/Dane_miesieczne.html
} 
to tempo wzrostu zbliżone do charakterystyk całego sektora banków spółdzielczych w Polsce (37,05\%). Istniały przy tym znaczące dysproporcje w dynamice rozwoju, bowiem wartość aktywów dużych banków spółdzielczych wzrosła w tym okresie niemal dwukrotnie więcej niż małych banków spółdzielczych (rysunek 2). Oznacza to pogłębianie się dysproporcji pomiędzy bankami małymi o lokalnym charakterze, które rozwijają się w okresie pokryzysowym zdecydowanie wolniej niż banki duże, coraz bardziej zatracające lokalny charakter.

Rysunek 2. Przeciętna dynamika wzrostu aktywów banków spółdzielczych w latach 2011-2013 według grup $($ rok $2010=100)$

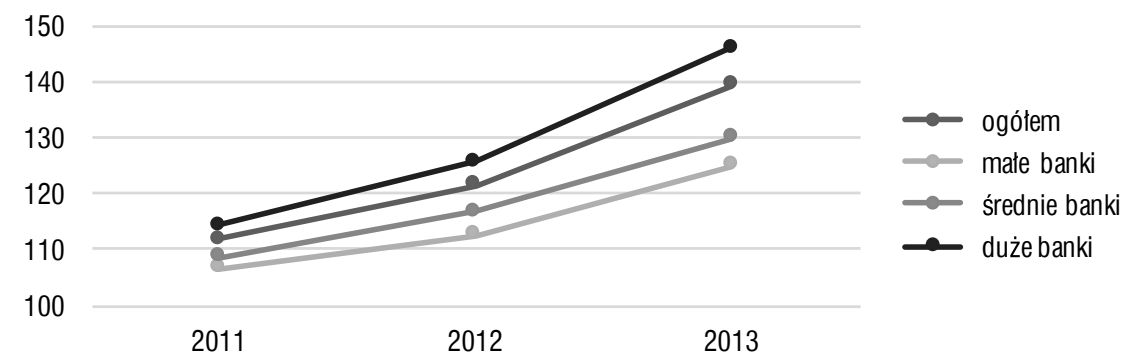

Źródło: Opracowanie własne na podstawie danych udostępnionych przez BPS S.A.

Od 2012 r. istnieje w badanej grupie zjawisko znaczącego zmniejszenia wartości wskaźników rentowności (o ok. 4 p.p. łącznie w latach 2012 i 2013), przy czym duże banki spółdzielcze charakteryzują w całym badanym okresie znacząco wyższe wartości ROE (rysunek 3). Konsekwencją możliwości generowania wyższej stopy zwrotu z kapitałów własnych jest jednak zdecydowanie niższy poziom wskaźników wypłacalności i stabilności (CAR, Z-score) tej grupy banków w stosunku do banków średnich i małych. W grupie małych banków zaobserwowano w roku 2013 największe zmniejszenie wartości CAR i Z-score, wynikające przede wszystkim ze znaczącego zmniejszenia wyniku finansowego w tym okresie, jednak nadal ocena bezpieczeństwa wszystkich badanych banków pozostaje wysoka (rysunek 3).

Po okresie utrzymującego się w latach 2010-2012 względnie stabilnego poziomu zaangażowania analizowanych banków spółdzielczych w kredytowanie sektora finansowego, w roku 2013 obserwowane jest zdecydowane obniżenie udziału kredytów dla sektora niefinansowego w aktywach (rysunek 4). Jedną z istotnych przyczyn takiego stanu rzeczy jest przede wszystkim zmniejszenie ekspozycji kredytów dla gospodarstw domowych. Obserwowana jest jednocześnie tendencja istotnego zwiększania zaangażowania banków spółdzielczych w kredytowanie przedsiębiorstw, które do tej pory nie stanowiły ich podstawowego rynku. Trend ten jest szczególnie 
zauważalny w wypadku banków dużych, dla których ekspozycje kredytów korporacyjnych stanowiły w 2013 r. już blisko 17\% aktywów (w bankach średnich i małych odpowiednio $8,4 \%$ i $6,6 \%)$.

Rysunek 3. Wartość średnia wskaźników: ROE (lewa strona), CAR (środek) oraz Z-score dla banków spółdzielczych według grup w latach 2010-2013 (w \%)
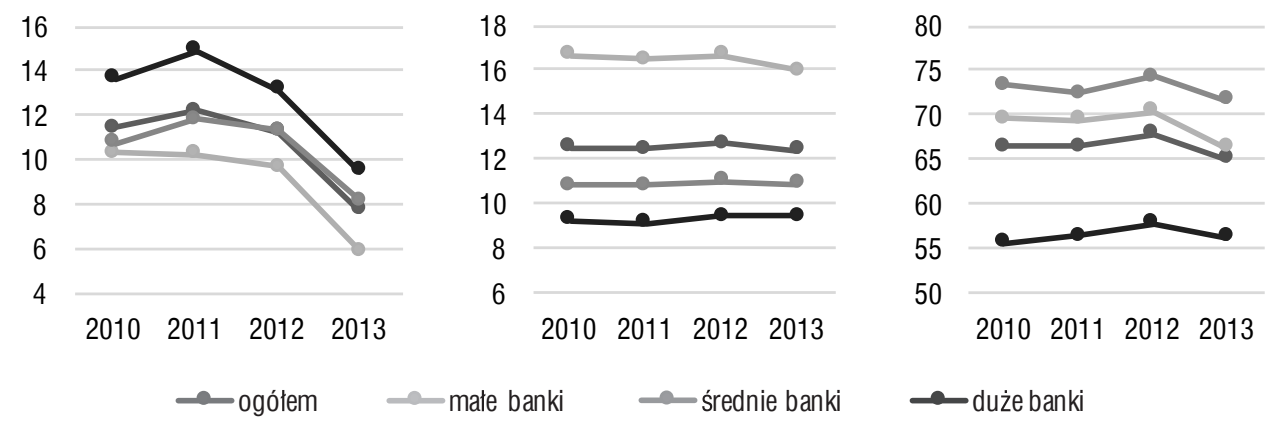

Źródło: Opracowanie własne na podstawie danych udostępnionych przez BPS S.A.

Rysunek 4. Wartość średnia wskaźników: kredyty ogółem dla sektora niefinansowego/suma aktywów (lewa strona) oraz kredyty dla przedsiębiorstw/suma aktywów (prawa strona) dla banków spółdzielczych w latach 2010-2013 według grup (w \%)
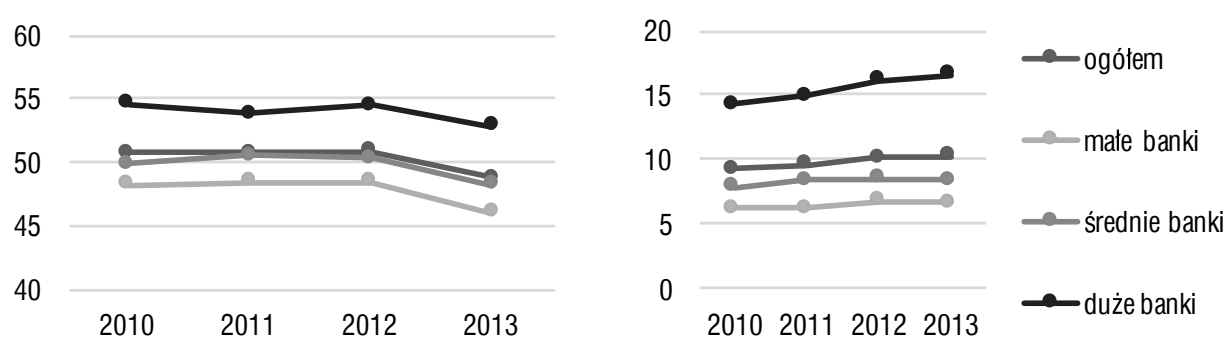

Źródło: Opracowanie własne na podstawie danych udostępnionych przez BPS S.A.

W latach 2010-2013 zaobserwowano we wszystkich badanych grupach banków spółdzielczych znaczące pogorszenie jakości kredytów. Wartość NPL ogółem wzrosła w tym okresie we wszystkich grupach dość proporcjonalnie, o ok. 1-1,5 p.p., przy czym najwyższa pozostała wśród dużych banków. Szczególnie interesujące są zmiany dotyczące jakości kredytów dla przedsiębiorstw. Wartość NPL dla tej grupy należności w małych bankach spółdzielczych wzrosła w latach 2010-2012 o blisko 150\%, do poziomu 10\% ogółu należności. Podobne wartości charakteryzowały w roku 2012 
wszystkie badane grupy banków spółdzielczych. W wypadku banków dużych wzrost wartości wskaźnika NPL kredytów dla gospodarstw domowych i przedsiębiorstw nie różnił się znacząco (rysunek 5).

\section{Rysunek 5. Wartość średnia wskaźnika NPL ogółem (lewa strona) NPL kredytów dla przedsiębiorstw (środek) oraz NPL kredytów dla gospodarstw domowych (prawa strona) dla banków spółdzielczych w latach 2010-2013 według grup $(\mathrm{w} \%)$}
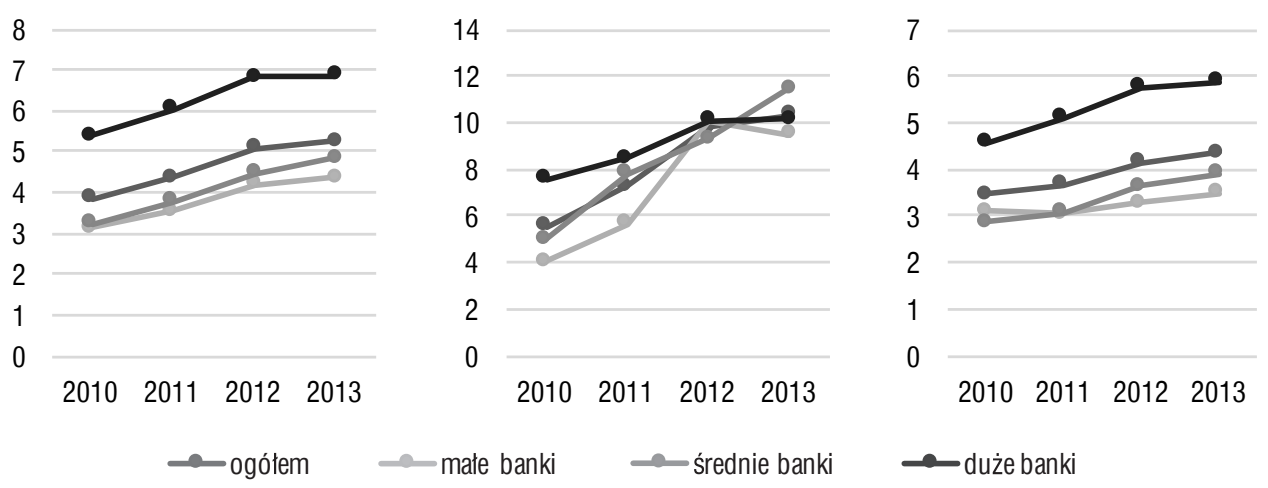

Źródło: Opracowanie własne na podstawie danych udostępnionych przez BPS S.A.

\section{Wyniki modelu}

W pierwszym modelu panelowym dokonano weryfikacji hipotezy badawczej dotyczącej istotności wpływu czynników makroekonomicznych i mikroekonomicznych na podaż i strukturę portfela kredytowego banków spółdzielczych oraz kierunku wpływu tych czynników na podaż kredytów. Wyniki ujęto sumarycznie w tabeli 1.

Badanie panelowe pokazało znacznie słabsze oddziaływanie czynników zewnętrznych - makroekonomicznych niż mikroekonomicznych, związanych z modelem biznesowym i wynikami finansowymi banku. Wśród czynników makroekonomicznych wysoka dynamika PKB per capita w danym województwie ujemnie oddziaływała na udział kredytów ogółem w aktywach i udział kredytów dla przedsiębiorstw w portfelu kredytowym, natomiast pozytywnie na udział kredytów dla gospodarstw domowych w portfelu kredytów dla sektora niefinansowego. Szybki wzrost produkcji na mieszkańca pozytywnie wpływa zatem na wzrost roli banków spółdzielczych w zaspokajaniu potrzeb kredytowych gospodarstw domowych. Stopy procentowe (WIBOR) były nieistotne. 
Tabela 1. Czynniki wpływające na wielkość i strukturę portfela kredytowego banków spółdzielczych w latach 2010-2013

\begin{tabular}{|c|c|c|c|c|c|c|}
\hline \multirow{2}{*}{$\begin{array}{l}\text { Zmienna } \\
\text { Wyraz wolny }\end{array}$} & \multicolumn{2}{|c|}{ Kogółem/A } & \multicolumn{2}{|c|}{ Kprz/ Kogółem } & \multicolumn{2}{|c|}{ Kgd/ Kogółem } \\
\hline & 1633,64 & $\star * *$ & $-52,449$ & $* * *$ & 146,062 & *** \\
\hline & $(80,649)$ & & $(11,675)$ & & $(11,386)$ & \\
\hline \multirow[t]{2}{*}{$\Delta \mathrm{PKB}$} & $-3,210$ & $* * *$ & $-0,406$ & $* * *$ & 0,383 & $* * *$ \\
\hline & $(0,512)$ & & $(0,073)$ & & $(0,072)$ & \\
\hline \multirow[t]{2}{*}{ WIBOR 0/N } & 0,120 & & 0,082 & & $-0,088$ & \\
\hline & $(1,105)$ & & $(0,159)$ & & $(0,155)$ & \\
\hline \multirow[t]{2}{*}{ logAktywa } & $-345,298$ & $* * *$ & 15,18 & & $-14,43$ & $* * *$ \\
\hline & $(15,872)$ & & $(2,270)$ & & $(2,238)$ & \\
\hline \multirow[t]{2}{*}{ Zatrudnienie } & 1,473 & $* * *$ & 0,094 & $* * *$ & $-0,087$ & $* * *$ \\
\hline & $(0,217)$ & & $(0,030)$ & & $(0,031)$ & \\
\hline \multirow[t]{2}{*}{ ROE } & $-0,739$ & *** & $-0,050$ & & 0,051 & \\
\hline & $(0,237)$ & & $(0,033)$ & & $(0,033)$ & \\
\hline \multirow[t]{2}{*}{ CAR } & 12,690 & $\star * *$ & 0,267 & $* * *$ & $-0,184$ & \\
\hline & $(1,230)$ & & $(0,187)$ & & $(0,174)$ & \\
\hline \multirow[t]{2}{*}{ Z-score } & $-1,773$ & $* * *$ & $-0,057$ & * & 0,068 & ** \\
\hline & $(0,231)$ & & $(0,033)$ & & $(0,033)$ & \\
\hline \multirow[t]{2}{*}{$\mathrm{D} / \mathrm{K}$} & 14,168 & $* * *$ & $-3,346$ & $* * *$ & 3,633 & $* * *$ \\
\hline & $(4,226)$ & & $(0,627)$ & & $(0,595)$ & \\
\hline \multirow[t]{2}{*}{ NPL ogółem } & 0,122 & & - & & - & \\
\hline & $(0,372)$ & & & & & \\
\hline \multirow[t]{2}{*}{ NPL prz } & - & & $-0,045$ & $* * *$ & & \\
\hline & & & $(0,012)$ & & & \\
\hline \multirow[t]{2}{*}{ NPL gd } & - & & - & & $-0,012$ & \\
\hline & & & & & $(0,053)$ & \\
\hline $\mathrm{R}^{2}$ & \multicolumn{2}{|l|}{0,661} & \multicolumn{2}{|l|}{0,965} & \multicolumn{2}{|l|}{0,966} \\
\hline Skorygowany R² & 0,544 & & 0,952 & & 0,954 & \\
\hline
\end{tabular}

Uwaga: ${ }^{* *}$ istotność na poziomie $1 \%,{ }^{* *}$ istotność na poziomie $5 \%,{ }^{*}$ istotność na poziomie $10 \%$.

Źródło: Opracowanie własne.

Wśród czynników mikroekonomicznych łatwiej wyodrębnić te, które negatywnie wpływają na wielkość i strukturę kredytów, niż mające pozytywny wpływ. Na kredyty ogółem (w relacji do sumy aktywów) i na kredyty dla przedsiębiorstw (w relacji do ogółu kredytów dla sektora niefinansowego) jednoznacznie pozytywnie oddziałuje tylko silny kapitał banku.

Większość czynników oddziałuje negatywnie na kredyty ogółem i kredyty dla przedsiębiorstw, na przykład wielkość banku. Wzrost wartości wskaźnika depozytów w stosunku do kredytów wpływa ujemnie na udział kredytów dla przedsiębiorstw 
w kredytach ogółem, ale pozytywnie na wartość wskaźników kredyty ogółem/aktywa oraz kredyty dla gospodarstw domowych/kredyty ogółem. Wzrost poziomu bezpieczeństwa banku (mierzonego Z-score), podobnie jak wzrost PKB, powoduje zmniejszenie udziału kredytów ogółem w strukturze aktywów i kredytów dla przedsiębiorstw w kredytach ogółem, natomiast wzrost udziału w strukturze kredytów należności od gospodarstw domowych. Jakość ekspozycji kredytowych miała wpływ jedynie na kredyty dla przedsiębiorstw. Niższa wartość NPL dla tej grupy kredytów wiązała się z wyższym udziałem kredytów dla przedsiębiorstw w kredytach dla sektora niefinansowego. Zaskakujący jest negatywny związek miedzy wzrostem PKB i zmiennymi Kogółem/A oraz Kprz/ Kogółem. Również wzrost rentowności negatywnie oddziałuje na udział kredytów gospodarczych w kredytach ogółem, co może świadczyć o tym, że szybki wzrost gospodarczy i wysoka dynamika rentowności stanowią istotną przesłankę do wzmacniania kredytowania potrzeb gospodarstw domowych kosztem przedsiębiorców, którzy w warunkach koniunktury gospodarczej mogą poszukiwać też alternatywnych źródeł finansowania, m.in. na rynku kapitałowym.

Jak pokazano w części czwartej, w której dokonano charakterystyki badanych grup banków spółdzielczych, pogłębia się zróżnicowanie strategii i wyników wewnątrz grup banków małych, średnich i dużych. Jednak wyniki badania panelowego, w którym zmienną objaśnianą był udział kredytów dla przedsiębiorstw w kredytach dla sektora niefinansowego, przedstawione $\mathrm{w}$ tabeli $2 \mathrm{w}$ podziale na grupy, nie są tak istotne, jak w wypadku badania całej zbiorowości. Kredyty dla przedsiębiorstw były dodatnio skorelowane $\mathrm{z}$ wielkością banku we wszystkich grupach, a z kapitałem tylko w wypadku banków dużych. Inne istotne czynniki (wzrost PKB, depozyty do kredytów i NPL) miały ujemny wpływ na badaną zmienną.

Tabela 2. Czynniki wpływające na wielkość i strukturę portfela kredytowego banków spółdzielczych w podziale na grupy w latach 2010-2013

\begin{tabular}{|l|c|c|c|c|c|c|}
\hline \multicolumn{1}{|c|}{ Zmienna } & \multicolumn{3}{c|}{ Kprz/ Kogótem } \\
\hline & \multicolumn{2}{|c|}{ Małe banki } & \multicolumn{2}{c|}{ Średnie banki } & \multicolumn{2}{c|}{ Duże banki } \\
\hline Wyraz wolny & $-41,115$ & & $-77,746$ & $* * *$ & $-112,978$ & $* *$ \\
\hline & $\mathbf{( 3 5 , 0 2 1 )}$ & & $\mathbf{( 1 9 , 0 3 3 )}$ & & $\mathbf{( 1 6 , 5 4 4 )}$ & \\
\hline$\Delta$ PKB & $-0,549$ & $* * *$ & 0,033 & & $-0,365$ & $* * *$ \\
\hline & $(0,141)$ & & $(0,105)$ & & $(0,123)$ & \\
\hline WIBOR 0/N & 0,100 & & 0,186 & & $-0,020$ & \\
\hline & $\mathbf{( 0 , 3 2 4 )}$ & & $(0,214)$ & & $\mathbf{( 0 , 2 5 5 )}$ & \\
\hline logAktywa & 16,947 & $* *$ & 18,339 & $* * *$ & 25,439 & $* * *$ \\
\hline & $\mathbf{( 7 , 0 7 2 )}$ & & $\mathbf{( 3 , 8 0 5 )}$ & & $\mathbf{( 3 , 1 0 7 )}$ & \\
\hline Zatrudnienie & 0,080 & & 0,110 & & 0,046 & \\
\hline
\end{tabular}




\begin{tabular}{|c|c|c|c|c|c|c|}
\hline \multirow[t]{3}{*}{ Zmienna } & \multicolumn{6}{|c|}{ Kprz/ Kogółem } \\
\hline & \multicolumn{2}{|c|}{ Małe banki } & \multicolumn{2}{|c|}{ Średnie banki } & \multicolumn{2}{|c|}{ Duże banki } \\
\hline & $(0,109)$ & & $(0,078)$ & & $(0,033)$ & \\
\hline \multirow[t]{2}{*}{$\mathrm{ROE}$} & $-0,095$ & & 0,062 & & 0,014 & \\
\hline & $(0,071)$ & & $(0,047)$ & & $(0,050)$ & \\
\hline \multirow[t]{2}{*}{ CAR } & $-0,318$ & & $-0,530$ & * & 2,077 & *** \\
\hline & $(0,381)$ & & $(0,321)$ & & $(0,348)$ & \\
\hline \multirow[t]{2}{*}{ Z-score } & $-0,074$ & & 0,047 & & $-0,188$ & *** \\
\hline & $(0,100)$ & & $(0,040)$ & & $(0,063)$ & \\
\hline \multirow[t]{2}{*}{$\mathrm{D} / \mathrm{K}$} & $-5,916$ & $* * *$ & 0,602 & & $-5,351$ & $* * *$ \\
\hline & $(1,014)$ & & $(0,960)$ & & $(1,373)$ & \\
\hline NPL ogółem & - & & - & & - & \\
\hline \multirow[t]{2}{*}{ NPL prz } & $-0,051$ & ** & $-0,044$ & $* *$ & $-0,050$ & * \\
\hline & $(0,020)$ & & $(0,018)$ & & $(0,028)$ & \\
\hline NPL gd & - & & - & & - & \\
\hline $\mathrm{R}^{2}$ & \multicolumn{2}{|l|}{0,947} & \multicolumn{2}{|l|}{0,967} & \multicolumn{2}{|l|}{0,978} \\
\hline Skorygowany $\mathrm{R}^{2}$ & \multicolumn{2}{|l|}{0,926} & \multicolumn{2}{|l|}{0,955} & \multicolumn{2}{|l|}{0,969} \\
\hline
\end{tabular}

Uwaga: ${ }^{* *}$ istotność na poziomie $1 \%,{ }^{* *}$ istotność na poziomie $5 \%,{ }^{*}$ istotność na poziomie $10 \%$. Źródło: Opracowanie własne.

W związku z tym, że udział kredytów z utratą wartości nie okazał się czynnikiem istotnie wpływającym na politykę kredytową banków spółdzielczych dla całego zbioru analizowanego $\mathrm{w}$ tabeli 1 , choć był istotny i negatywny dla badania panelowego $\mathrm{w}$ podziale na grupy banków przedstawionego $\mathrm{w}$ tabeli 2 , przeprowadzono dodatkowe badanie pokazujące, jakie czynniki wpływają na jakość portfela kredytowego badanych banków spółdzielczych (tabela 3).

Tabela 3. Czynniki wpływające na jakość portfela kredytowego banków spółdzielczych w latach 2010-2013

\begin{tabular}{|l|c|c|c|c|c|c|}
\hline \multicolumn{1}{|c|}{ Zmienna } & \multicolumn{2}{|c|}{ NPL ogótem } & \multicolumn{2}{c|}{ NPL prz. } & \multicolumn{2}{c|}{ NPL gd. } \\
\hline Wyraz wolny & $-\mathbf{2 0 , 8 0 3}$ & $* * *$ & $-\mathbf{1 3 3 , 6 0 2}$ & $* * *$ & $-\mathbf{1 8 , 0 4 2}$ & $* *$ \\
\hline & $(7,888)$ & & $(34,117)$ & & $(8,048)$ & \\
\hline$\Delta$ PKB & $-\mathbf{0 , 1 5 0}$ & $* * *$ & $-\mathbf{0 , 3 4 6}$ & $*$ & $-\mathbf{0 , 1 2 0}$ & $* \star *$ \\
\hline & $(0,043)$ & & $(0,193)$ & & $(0,043)$ & \\
\hline WIBOR 0/N & 0,327 & $* * *$ & 0,936 & $* *$ & 0,099 & \\
\hline & $(0,091)$ & & $(0,410)$ & & $(0,090)$ & \\
\hline logAktywa & $\mathbf{5 , 1 2 4}$ & $* * *$ & 25,446 & $* * *$ & $\mathbf{4 , 3 1 6}$ & $* *$ \\
\hline & $(1,583)$ & & $(6,839)$ & & $(1,604)$ & \\
\hline Zatrudnienie & $-\mathbf{0 , 0 3 3}$ & & $-\mathbf{0 , 1 8 0}$ & $* *$ & $\mathbf{0 , 0 2 7}$ & \\
\hline
\end{tabular}




\begin{tabular}{|l|c|c|c|c|c|c|}
\hline \multicolumn{1}{|c|}{ Zmienna } & \multicolumn{2}{c|}{ NPL ogótem } & \multicolumn{2}{c|}{ NPL prz. } & \multicolumn{2}{c|}{ NPL gd. } \\
\hline & $(0,018)$ & & $(0,080)$ & & $(0,018)$ & \\
\hline R0E & $-\mathbf{0 , 1 0 4}$ & $* * *$ & $-0,152$ & $*$ & $-0,057$ & $* * *$ \\
\hline & $(0,020)$ & & $(0,086)$ & & $(0,019)$ & \\
\hline CAR & $\mathbf{0 , 0 1 9}$ & & $\mathbf{0 , 7 6 6}$ & & 0,002 & \\
\hline & $(0,107)$ & & $(0,518)$ & & $(0,106)$ & \\
\hline Z-score & $\mathbf{0 , 0 0 1}$ & & $\mathbf{0 , 0 2 4}$ & & $-\mathbf{0 , 0 0 9}$ & \\
\hline & $(0,020)$ & & $(0,089)$ & & $(0,019)$ & \\
\hline D/K & $\mathbf{1 , 1 1 7}$ & $* * *$ & $\mathbf{8 , 2 3 9}$ & $* * *$ & $\mathbf{0 , 0 3 2}$ & \\
\hline & $(0,352)$ & & $(1,617)$ & & $(0,346)$ & \\
\hline Kogótem/A & 0,001 & & - & & - & \\
\hline & $(0,003)$ & & & & & \\
\hline Kprz/A & - & & $\mathbf{0 , 0 1 4}$ & & - & \\
\hline & & & $(0,020)$ & & & \\
\hline Kgd/A & - & & - & & 0,007 & \\
\hline & & & & & $(0,006)$ & \\
\hline$R^{2}$ & 0,889 & & 0,790 & & 0,882 & \\
\hline Skorygowany $\mathrm{R}^{2}$ & 0,850 & & 0,678 & & 0,841 & \\
\hline
\end{tabular}

Uwaga: ${ }^{* *}$ istotność na poziomie $1 \%,{ }^{* *}$ istotność na poziomie $5 \%,{ }^{*}$ istotność na poziomie $10 \%$. Źródło: Opracowanie własne.

Dane przedstawione w tabeli 3 pokazują, że do wzrostu portfela złych kredytów, zgodnie z wynikami modelu, przyczyniać się mogą głównie szybki wzrost stóp procentowych i silna baza depozytowa - istotne dla kredytów ogółem oraz dla przedsiębiorstw, a także wzrost wielkości banku istotny dla wszystkich grup kredytów. Pozytywnie na obniżenie wskaźnika NPL wpływał wzrost gospodarczy oraz poprawa rentowności banków.

\section{Podsumowanie}

Sposób generowania zysku zależy od modelu biznesowego banku, a ten od skali działania i ładu korporacyjnego narzuconego przez właścicieli. Kryzys finansowy uwidocznił zalety alternatywnych modeli biznesowych banków, nastawionych nie tylko na maksymalizację krótkoterminowych zysków, ale także realizację celów społecznych, szczególnie bankowości spółdzielczej. Istotną przewagą bankowości spółdzielczej w ostatnich latach okazała się elastyczność działania, dobra znajomość rynku lokalnego oraz podejście relacyjne do klientów. Pozwoliło to, szczególnie większym 
bankom spółdzielczym, aktywnie zwiększyć akcję kredytową dla sektora przedsiębiorstw. Jednak nowa strategia banków spółdzielczych - zwiększająca zakres ryzykownego kredytowania dla przedsiębiorstw - niesie także zagrożenia, związane ze wzrostem ryzyka, toteż istotnym wnioskiem wynikającym $z$ badań panelowych było wskazanie na podstawową rolę silnego kapitału banku jako czynnika stymulującego kredyty gospodarcze.

\section{Bibliografia}

Beck T., Büyükkarabacak B., Rioja F., Valev N., Who Gets the Credit? And Does It Matter? Household vs. Firm Lending across Countries, "The World Bank Working Paper" 2008, No. 4661.

Beck T., Degryse H., De Haas R., Van Horen N., When Arm's Length Is Too Far: Relationship Banking over the Business Cycle, "EBRD Working Paper" 2014, No. 169.

Beck T., Demirgüç-Kunt A., Soledad M., Peria M., Bank Financing for SMEs: Evidence Across Countries and Bank Ownership Types, "Journal of Financial Services Research" 2011, No. 39.

Bolton P., Freixas X., Gambacorta L., Mistrulli P.E., Relationship and Transaction Lending in a Crisis, "BIS Working Papers" 2013, No. 417.

Bongini P., Di Battista M.L., Nieri L., Relationship banking: an old solution for the present crisis?, BANCARIA, "Bancaria Editrice" 2009, Vol. 5.

Boot A., Relationship Banking: What Do We Know? "Journal of Financial Intermediation" 2000, No. 9.

Cappiello L., Kadareja A., Kok Sørensen Ch., Protopapa M., Do bank loans and credit standards have an effect on output? A panel approach for the euro area, "ECB Working Paper" 2010, No. 1150.

European Commission, Economic Review of the Financial Regulation Agenda, European Commission Staff Working Document, Brussels 2014.

Gajewski K., Pawłowska M., Rogowski W., Relacje firm z bankami w Polsce w świetle danych ze sprawozdawczości bankowej, „Materiały i Studia” 2012, nr 275, NBP.

Hasan I., Jackowicz K., Kowalewski O., Kozłoski Ł., Bank ownership structure, SME lending and local credit markets, "Bank of Finland Research Discussion Paper" 2014, No. 22.

KNF, Informacja o sytuacji banków spółdzielczych i zrzeszających w I kwartale $2014 \mathrm{r}$., Warszawa 2014.

McKinsey on Cooperatives, McKinsey \& Co., 2012, www.mckinsey.com.

McCarroll V., Habberfield S., The Outlook for Co-Operative Banking in Europe, Oliver Wyman Report, 2012, www.oliverwyman.com 
Wstępne szacunki produktu krajowego brutto wedlug województw w 2013 r., GUS, Warszawa 27 stycznia 2015.

\section{Factors Influencing Corporate Loans Accessibility in the Post-Crisis Period: the Example of Polish Co-operative Banks}

The post-crisis period stressed the role of small, local banks in corporate lending, particularly for SME, due to such their advantages as being based on relationship banking and extensive knowledge of local market. However, it is still unclear whether it is a short or long-term advantage. The aim of this paper is to analyze the factors affecting the size and quality of the loan portfolios of the Polish cooperative banks. In the empirical part, the study is based on statistical data and panel research, based on individual balance sheet data for the banks affiliated to the BPS SA. The results confirm that the role of cooperative banks in lending to businesses increases, but also pointed to internal diversity of the sector in this area: growth in loans to the corporate sector was particularly strong for large banks with strong capital, but also resulted in their declining safety and increasing bad loans portfolio.

Keywords: cooperative banks, corporate loans, SMEs loans

\section{Les facteurs qui influencent l'accessibilité aux prêts aux entreprises dans la période post-crise: l'exemple des banques coopératives polonaises}

La période post-crise a souligné le rôle de petites banques locales dans les prêts aux entreprises, en particulier pour les PME, en raison de leurs avantages tels que: être basé sur la relation bancaire et une connaissance approfondie du marché local. Cependant, il est encore difficile de savoir s'il s'agit d'un avantage à court ou à long terme. Le but de cet article est d'analyser les facteurs qui influent sur la taille et la qualité des portefeuilles des prêts des banques coopératives polonaises. Dans sa partie empirique, l'analyse est basée sur les données statistiques et l'étude de panel qui se réfère aux données sur les banques affiliées à la BPS SA. Les résultats confirment que le rôle des banques coopératives dans les prêts aux entreprises augmente, mais ils soulignent également la diversité interne du secteur dans ce domaine: le développement des prêts au secteur privé a été particulièrement élevée 
pour les grandes banques, mais il a aussi contribué à la diminution de la sécurité des transactions et à la croissance de 'mauvais prêts'.

Mots-clés: les banques coopératives, les prêts aux entreprises, les prêts aux PME

\section{Факторы, влияющие на доступность корпоративных кредитов в посткризисный период. Казус кооперативных банков в Польше}

Посткризисный период указал роль небольших местных банков в корпоративном кредитовании, в частности, малого и среднего бизнеса. Их преимущества связаны с ведением банковских операций на условиях доверительных партнерских отношений с клиентом и обширным знанием местного рынка. Тем не менее, до сих пор неясно являются ли они краткосрочными или долгосрочными преимуществами. Цель статьи состоит в анализе факторов, влияющих на размер и качество кредитных портфелей польских кооперативных банков. В эмпирической части исследование основано на статистических данных и анализе панельных данных для банков, входящих в BPS SA. Результаты подтвердили рост значения кооперативных банков в кредитовании предприятий, но также указали внутреннюю неоднородность сектора в этой области. Увеличение кредитования корпоративного сектора наблюдалось особенно сильно среди крупных банков с большим капиталом. Этому сопутствовало снижение уровня безопасности и увеличение портфеля плохих кредитов.

Ключевые слова: кооперативные банки, корпоративные кредиты, финансирование сектора МСП 
Aneks statystyczny (wartości podkreślone - średnia arytmetyczna z próby, kursywa - odchylenie standardowe $z$ próby)

\begin{tabular}{|c|c|c|c|c|c|c|c|c|c|c|c|c|c|c|c|c|}
\hline \multirow{3}{*}{ Zmienna } & \multicolumn{4}{|c|}{2010} & \multicolumn{4}{|c|}{2011} & \multicolumn{4}{|c|}{2012} & \multicolumn{4}{|c|}{2013} \\
\hline & \multicolumn{4}{|c|}{ grupa banków spółdzielczych } & \multicolumn{4}{|c|}{ grupa banków spółdzielczych } & \multicolumn{4}{|c|}{ grupa banków spółdzielczych } & \multicolumn{4}{|c|}{ grupa banków spółdzielczych } \\
\hline & ogółem & małe & średnie & duże & ogótem & małe & średnie & duże & ogótem & małe & średnie & duże & ogółem & małe & średnie & duże \\
\hline \multirow{2}{*}{$\begin{array}{l}\text { Aktywa } \\
\text { (mln zł) }\end{array}$} & 117,16 & $\underline{38,26}$ & $\underline{81,89}$ & $\underline{251,81}$ & $\underline{130,95}$ & $\underline{40,82}$ & $\underline{88,99}$ & $\underline{287,70}$ & 142,22 & $\underline{43,05}$ & $\underline{95,57}$ & $\underline{316,09}$ & 163,01 & $\underline{47,81}$ & 106,40 & $\underline{367,60}$ \\
\hline & 149,41 & 13,06 & 19,89 & 214,03 & 173,94 & 13,05 & 21,07 & 251,36 & 197,36 & 14,05 & 21,41 & 289,91 & 258,40 & 15,55 & 22,70 & 399,57 \\
\hline \multirow{2}{*}{ ROE (\%) } & $\underline{11,44}$ & $\underline{10,27}$ & $\underline{10,75}$ & $\underline{13,63}$ & $\underline{12,16}$ & $\underline{10,25}$ & $\underline{11,79}$ & $\underline{14,92}$ & $\underline{11,23}$ & $\underline{9,64}$ & $\underline{11,29}$ & $\underline{13,15}$ & $\underline{7,68}$ & $\underline{5,88}$ & $\underline{8,14}$ & $\underline{9,45}$ \\
\hline & 4,78 & 2,78 & 6,48 & 3,85 & 4,98 & 3,79 & 3,51 & 6,25 & 4,41 & 3,75 & 4,53 & 4,29 & 4,71 & 5,35 & 2,94 & 4,61 \\
\hline \multirow{2}{*}{$\begin{array}{l}\text { Kredyty ogółem/suma } \\
\text { aktywów (\%) }\end{array}$} & $\underline{50,69}$ & $\underline{48,22}$ & $\underline{49,90}$ & $\underline{54,57}$ & $\underline{50,70}$ & $\underline{48,36}$ & $\underline{50,51}$ & $\underline{53,82}$ & $\underline{50,84}$ & $\underline{48,44}$ & $\underline{50,26}$ & $\underline{54,46}$ & $\underline{48,77}$ & $\underline{46,02}$ & $\underline{48,22}$ & $\underline{52,80}$ \\
\hline & 14,66 & 14,45 & 12,33 & 16,40 & 13,65 & 14,80 & 12,78 & 12,52 & 13,72 & 14,54 & 12,88 & 12,86 & 13,56 & 14,66 & 12,43 & 12,39 \\
\hline \multirow{2}{*}{$\begin{array}{l}\text { Kredyty dla przedsiębiorstw/ } \\
\text { suma aktywów (\%) }\end{array}$} & $\underline{9,23}$ & $\underline{6,27}$ & $\underline{7,90}$ & $\underline{14,27}$ & $\underline{9,57}$ & $\underline{6,24}$ & $\underline{8,44}$ & $\underline{14,91}$ & $\underline{10,16}$ & $\underline{6,76}$ & $\underline{8,55}$ & $\underline{16,15}$ & 10,21 & $\underline{6,63}$ & $\underline{8,42}$ & $\underline{16,60}$ \\
\hline & 10,51 & 7,05 & 6,53 & 14,85 & 9,37 & 7,07 & 7,10 & 11,50 & 9,82 & 7,68 & 7,03 & 11,92 & 9,66 & 7,19 & 6,54 & 11,83 \\
\hline \multirow{2}{*}{$\begin{array}{l}\text { Kredyty dla gospodarstw } \\
\text { dom./suma aktywów (\%) }\end{array}$} & $\underline{40,90}$ & $\underline{41,48}$ & $\underline{41,39}$ & $\underline{39,69}$ & $\underline{40,49}$ & $\underline{41,49}$ & $\underline{41,39}$ & $\underline{38,28}$ & $\underline{40,07}$ & $\underline{41,09}$ & $\underline{41,10}$ & $\underline{37,70}$ & 37,97 & $\underline{38,76}$ & $\underline{39,21}$ & 35,64 \\
\hline & 13,82 & 15,33 & 13,23 & 12,44 & 14,51 & 15,94 & 13,88 & 13,14 & 14,99 & 16,72 & 13,93 & 13,58 & 14,71 & 16,66 & 13,13 & 13,53 \\
\hline \multirow{2}{*}{ CAR (\%) } & $\underline{12,53}$ & $\underline{16,63}$ & $\underline{10,80}$ & $\underline{9,25}$ & $\underline{12,41}$ & $\underline{16,45}$ & $\underline{10,79}$ & $\underline{9,12}$ & $\underline{12,67}$ & $\underline{16,66}$ & $\underline{11,01}$ & $\underline{9,44}$ & $\underline{12,38}$ & $\underline{15,98}$ & $\underline{10,90}$ & $\underline{9,44}$ \\
\hline & 5,02 & 5,40 & 2,44 & 2,44 & 4,71 & 5,00 & 2,33 & 1,71 & 4,68 & 4,94 & 2,28 & 1,84 & 4,45 & 4,86 & 2,30 & 1,81 \\
\hline \multirow{2}{*}{ Z-score (jedn.) } & $\underline{66,49}$ & $\underline{69,52}$ & $\underline{73,26}$ & $\underline{55,58}$ & $\underline{66,44}$ & $\underline{69,48}$ & $\underline{72,35}$ & $\underline{56,36}$ & $\underline{67,82}$ & $\underline{70,35}$ & $\underline{74,20}$ & $\underline{57,85}$ & $\underline{64,96}$ & $\underline{66,31}$ & $\underline{71,58}$ & $\underline{56,22}$ \\
\hline & 45,79 & 38,61 & 59,56 & 34,25 & 43,60 & 38,29 & 54,16 & 35,04 & 45,20 & 38,51 & 57,14 & 36,44 & 43,82 & 37,38 & 55,34 & 35,60 \\
\hline \multirow{2}{*}{ NPL ogółem (\%) } & $\underline{3,84}$ & $\underline{3,12}$ & $\underline{3,23}$ & $\underline{5,40}$ & $\underline{4,35}$ & $\underline{3,53}$ & $\underline{3,77}$ & $\underline{6,02}$ & $\underline{5,07}$ & $\underline{4,17}$ & $\underline{4,47}$ & $\underline{6,82}$ & $\underline{5,26}$ & $\underline{4,35}$ & 4,82 & $\underline{6,86}$ \\
\hline & 5,22 & 4,63 & 3,84 & 6,70 & 5,82 & 5,21 & 4,58 & 7,24 & 5,95 & 5,46 & 4,98 & 7,07 & 5,43 & 4,83 & 5,07 & 6,17 \\
\hline \multirow{2}{*}{$\begin{array}{l}\text { NPL kredyty dla } \\
\text { przedsiębiorstw (\%) }\end{array}$} & $\underline{5,54}$ & $\underline{4,07}$ & $\underline{5,01}$ & $\underline{7,58}$ & $\underline{7,30}$ & $\underline{5,68}$ & $\underline{7,82}$ & $\underline{8,47}$ & $\underline{9,81}$ & $\underline{10,09}$ & $\underline{9,28}$ & $\underline{10,07}$ & $\underline{10,34}$ & $\underline{9,46}$ & $\underline{11,46}$ & $\underline{10,12}$ \\
\hline & 8,73 & 8,41 & 9,18 & 8,24 & 12,30 & 12,29 & 14,58 & 9,26 & 16,38 & 20,88 & 14,95 & 11,91 & 16,77 & 18,34 & 19,00 & 11,74 \\
\hline \multirow{2}{*}{$\begin{array}{l}\text { NPL gospodarstwa domowe } \\
(\%)\end{array}$} & $\underline{3,48}$ & $\underline{3,11}$ & $\underline{2,88}$ & $\underline{4,57}$ & $\underline{3,67}$ & $\underline{3,04}$ & $\underline{3,07}$ & $\underline{5,11}$ & $\underline{4,14}$ & $\underline{3,29}$ & $\underline{3,64}$ & $\underline{5,75}$ & $\underline{4,34}$ & $\underline{3,49}$ & $\underline{3,90}$ & $\underline{5,88}$ \\
\hline & 5,38 & 4,76 & 3,54 & 7,29 & 5,44 & 4,45 & 3,73 & 7,49 & 5,50 & 4,33 & 4,58 & 7,16 & 5,32 & 4,23 & 4,85 & 6,60 \\
\hline \multirow{2}{*}{ Depozyty/kredyty (\%) } & $\underline{1,61}$ & $\underline{1,65}$ & $\underline{1,64}$ & $\underline{1,54}$ & $\underline{1,62}$ & $\underline{1,65}$ & $\underline{1,67}$ & $\underline{1,55}$ & $\underline{1,63}$ & $\underline{1,64}$ & $\underline{1,69}$ & $\underline{1,54}$ & $\underline{1,73}$ & $\underline{1,78}$ & $\underline{1,78}$ & $\underline{1,61}$ \\
\hline & 0,58 & 0,70 & 0,52 & 0,47 & 0,57 & 0,62 & 0,59 & 0,46 & 0,58 & 0,60 & 0,65 & 0,46 & 0,61 & 0,63 & 0,69 & 0,48 \\
\hline
\end{tabular}

Źródło: Opracowanie własne. 
